\title{
一般内科医向きの排尿障害重症度評価基準
}

\author{
国立長寿医療センター泌尿器科 ${ }^{1)}$, 村山医療センター泌尿器科 ${ }^{21}$, \\ 国立精神神経センター国府台病院泌尿器科3) \\ 岡村 菊夫 ${ }^{1)}$ 長田 浩彦 ${ }^{2)}$ 長浜 克志 ${ }^{3)}$ \\ 野尻 佳克 ${ }^{1)}$ 加納 英人 ${ }^{3)}$ 宮崎 政美 ${ }^{33}$

\section{ASSESSMENT CRITERIA OF LOWER URINARY TRACT SYMPTOMS SEVERITY FOR GENERAL PRACTITIONERS}

\author{
Kikuo Okamura ${ }^{1)}$, Hirohiko Nagata ${ }^{2)}$, Katsushi Nagahama ${ }^{3)}$, \\ Yoshikatsu Nojiri ${ }^{1)}$, Hideto Kanoh $^{3)}$ and Masami Miyazaki ${ }^{3}$ \\ From the Departments of Urology, National Center for Geriatrics and Gerontology ${ }^{11}$, \\ Murayama Medical Center ${ }^{2}$, National Center of Neurology \& Psychiatry, Kohnodai Hospital ${ }^{3)}$
}

(Objectives) We conducted a preliminary study to examine the validity of assessment criteria of lower urinary tract symptoms (LUTS) severity for general practitioners (GPs).

(Materials and Methods) This study included 194 patients with LUTS, who visited the urology clinics in three hospitals. In 177 who completed International Prostate Symptom Score (I-PSS), International Consultation on Incontinence Questionnaire : Short-Form (ICIQ-SF), frequency-volume chart, uroflowmetry and post-void residual urine measurement, three overall grades (mild, moderate and severe) of LUTS were determined using the newly-developed assessment criteria for GPs. The relationship between diagnoses and treatments by the urologists, and overall LUTS grades were examined.

(Results) All of the 70 patients with "severe" grade and 68 (94\%) of 72 with "moderate" grade were diagnosed as having urination problems. Sixty-eight (97\%) with "severe" grade and 64 (89\%) with "moderate" grade were treated with fluid restriction, behavioral therapy, and/or drug therapy. Of 35 with "mild” grade, 17 (49\%) were diagnosed as having normal urination. In this grade, eight patients $(23 \%)$ were treated with fluid restriction and 15 (43\%) with drug therapy.

(Conclusions) This preliminary study revealed that our criteria of LUTS severity for GPs were useful to determine whether the elderly patients should be treated or not. It is necessary to examine the validity of the criteria in a model in which GPs participate.

Key words : lower urinary tract symptoms, general practitioner, assessment criteria

要旨：(目的）一般内科医向きの排尿障害重症度評価基準の有効性を検討する.

(対象と方法) 下部尿路症状を有し，3つの病院の泌尿器科を受診した 194 人を対象とした. 国際前立 腺症状スコア (I-PSS), 国際尿失禁会議質問票 (ICIQ-SF) の回答, 排尿記録の記載, 尿流測定, 残尿測 定のすべてが行われた 177 人の排尿障害に関する総合的重症度を，一般内科医向きに作成した評価基準 をもとに, 軽症, 中等症, 重症の 3 段階に判定した. この総合的重症度と泌尿器科医の診断, 治療との 関連を検討した.

（結果）重症と判定された 70 例すべて（100\%）と中等症と判定された 72 例中 68 例（94\%）は，泌尿 器科医によって何らかの排尿の問題があると診断された．また，重症の 68 例（97\%）と中等症の 64 例 （89\%）は, 水分制限, 行動療法, 薬物治療などで治療されていた. 軽症の 35 例中 17 例（49\%）が正常 の排尿であると判断された．軽症例でも 8 例 $(23 \%)$ で水分制限が，15例（43\%）で薬物治療が行われ ていた. 
（結論）この研究により,一般内科医向きの排尿障害重症度評価基準が高齢者の下部尿路症状を治療し た方がよいかどうかの判定に有用であることがわかった．今後，一般内科医の行う診療においてその有 用性の検討を行う必要がある.

キーワード：下部尿路症状, 一般内科医, 重症度評価基準

\section{はじめに}

他の先進諸国が経験したことのない速度で高齢化が 進行しているわが国では，高齢者の生活の質 $(\mathrm{QOL}) を$ 著しく障害する下部尿路症状は大いに注目を集めてい $る^{1) \sim 3)}$. 尿意切迫感を中心に頻尿, 切迫性尿失禁を伴 う過活動膀胱は高齢者によく見られるたいへん辛い症 状であり，前立腺肥大症に代表される膀胱出口閉塞や 排尿筋収縮力低下によりもたらされる尿勢低下，腹圧 排尿，尿線途絶といった症状も高齢者を悩ます症状で あるといえる．排出障害は，高齢男性ばかりでなく高

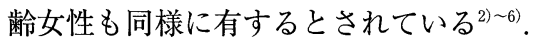

泌尿器科医による診療では, まず排尿に関する自覚 症状と困窮度を評価し, 次いで, 排尿日誌や尿流測定, 残尿測定などの検查から排尿に関する客観的デー夕を 収集する ${ }^{78)}$. 詳細な機能的デー夕を与えてくれる尿流 動態検査は侵襲的であるために，排尿障害を訴えるす べての患者に必ずしも実施されるわけではない.

本邦での疫学的研究によって, 40 歳以上の人口 6,600 万人のうち, 810 万人が過活動膀胱を, 2,100 万人 が尿失禁を, 2,500 万人が尿排出障害を有していること がわかった9). ちなみに欧米における過活動膀胱の頻 度は $16 \%$ 程度である ${ }^{10111}$ 。これだけ多数の中高年層 が排尿障害を有しているとすると, 泌尿器科医だけで 対応することはほぼ不可能であり，下部尿路症状の対 処について一般内科医のこの分野への参入が必要であ る. 教育さえ受ければ, 内科医であっても適切な行動 療法や薬物治療は可能であると考えられる ${ }^{12) ~ 15) . ~}$

しかし，一般内科医の排尿障害に対する知識はあま り深いとは言えない。それゆえに，一般内科医が患者 を治療すべきかどうか判定できるような簡便な評価基 準があると便利である ${ }^{816)}$ ：この研究では，3つの質問 票と残尿測定を用いた一般内科医向きに作成した評価 基準の有用性を検討した。

\section{対象と方法}

2003 年 7 月から 2004 年 3 月までに, 国立長寿医療 センター, 国立精神神経センター国府台病院, 村山医 療センター泌尿器科を受診した 194 人の患者を対象と し, 前向きにデー夕を収集した，尿路感染症, 泌尿器 癌, 尿路結石の患者は対象から除外した. 最終的に,
177 人 (91.2\%) の患者が国際前立腺症状スコア（IPSS), QOL スコア, 国際尿失禁会議質問票 (ICIQ-SF) を記載し，2３日の排尿記録をつけ，尿流測定および 残尿測定を受けた，男性では，超音波による前立腺容 積測定を行った ${ }^{1718)}$. 尿流動態検查は, 診断が難しい と考えられた一部の症例で施行された.

この研究では, 男女とも「正常の排尿」とは最大尿 流率 $15 \mathrm{ml} / \mathrm{sec}$ 以上かつ残尿 $50 \mathrm{ml}$ 未満で, かつ尿意切 迫感や尿失禁を有しないこととした，重症度に関して は, まず, I-PSS は 0〜7を軽度, 8〜19を中等度, 20〜 35 を高度とし，QOL スコアは 0,1 を軽度, 2〜4を中 等度, 5,6 を高度, 残尿量は $50 \mathrm{ml}$ 未満を軽度, $50 \mathrm{ml}$ 以上 $100 \mathrm{ml}$ 未満を中等度, $100 \mathrm{ml}$ 以上を高度と分類し た。一般内科医による排尿に関する重症度は，とりあ えず, I-PSS, QOL スコア, 残尿量によって軽症, 中等 症, 重症の 3 つに分類する. すなわち, 3 つの項目のう ち 2 つ以上が高度であれば排尿障害の重症度は重症, 高度が 1 つあるいは中等度以上が 2 つ以上あれば排尿 障害の重症度は中等症, 中等度が 1 つあるいは軽度が 2 つ以上あれば軽症とした.ささらに, 尿失禁を加味した 総合的重症度は, ICIQ-SF により尿失禁が認められた 場合, さきのI-PSS, QOL スコア, 残尿量の 3 つに よって決められた重症度を一っアップさせることとし た. 但し，もともとの排尿に関する重症度が重症であ れば重症のままとした.

排尿記録から昼間・夜間排尿回数, 24 時間ならびに 夜間尿量を計算した. 65 ７0 歳の日本人男性・女性の 平均体重は $62 \mathrm{~kg}, 54 \mathrm{~kg}$ であるため, この研究では, 男 性で 24 時間尿量が $2,480 \mathrm{ml}$ 以上，女性で $2,160 \mathrm{ml}$ 以上 $(40 \mathrm{ml} / \mathrm{kg})$ を多尿と定義した．夜間に 24 時間尿の 1 / 3 以上の尿量を認めた場合を夜間多尿とした ${ }^{4)}$.

この研究で泌尿器科医が行った治療は, 飲水 (カフェ イン含有飲料を含む) の制限, 膀胱訓練, 骨盤底筋体 操, $\alpha$ 交感神経遮断剂, 抗コリン剤, 抗男性ホルモン剂 などの薬物療法, 手術療法である. 泌尿器科医の診断 · 治療を「ゴールドスタンダード」とし，一般内科医向 きの評価基準による重症度と泌尿器科医の診断・治療 と比較検討した.

統計学的解析にはStatview Version 5.0 を用い, t 
検定, $\mathrm{x}^{2}$ 検定, ANOVA による 0.05 未満の $\mathrm{P}$ 值を有意 とした.

表 1 症例の背景

\begin{tabular}{|c|c|c|}
\hline & 男性（123） & 女性（54） \\
\hline $\begin{array}{l}\text { 年齢（歳） } \\
\text { 日常生活動作† }\end{array}$ & $70.5 \pm 7.6$ & $68.8 \pm 8.7$ \\
\hline 正常 & $97(79 \%)$ & $40(74 \%)$ \\
\hline 軽度障害 & $26(21 \%)$ & $14(26 \%)$ \\
\hline 認知機能 † & & \\
\hline 正常 & $111(90 \%)$ & $50(93 \%)$ \\
\hline 軽度障害 & $12(10 \%)$ & $4(7 \%)$ \\
\hline 主訴（重複を含む） & & \\
\hline 排尿困難 & 54 & 5 \\
\hline 頻尿 & 30 & 23 \\
\hline 夜間頻尿 & 17 & 6 \\
\hline 尿意切迫感 & 4 & 7 \\
\hline 尿失禁 & 8 & 14 \\
\hline その他 & 13 & 3 \\
\hline
\end{tabular}

$\dagger$ :日常生活動作と認知機能の障害度は「障害老人の日 常生活自立度（寝たきり度）判定基準」と「痴呆性老 人の日常生活自立度判定基準」によった，それぞれの 軽度障害はランク J, A とランク I とした。

\section{結 果}

表 1 に症例の背景を示す. 177 人のうち, 137 人は ADL 正常, 161 人の認知機能は正常と判断された. もっとも頻度の高い主訴は, 男性では排尿困難, 女性 では頻尿であった.

表 2 に, 総合的重症度診断と泌尿器科医による診断 との関係を示す．軽症 35 例中 17 例 $(49 \%)$ で正常の 排尿と判断されたのに比較して, 中等症では 72 例中 4 例 $(6 \%)$, 重症では 0 例であった。過活動膀胱は重症 度が進行するに従い, 両性ともその頻度を増したが, 前立腺肥大症/膀胱出口閉塞の頻度は中等症, 重症でも 変わらなかった. 多尿は, 男性で 18 人 (15\%), 女性 で 14 人 $(26 \%)$ に認められた，夜間多尿は，男性で 63 人 $(51 \%)$, 女性で 29 人 $(54 \%)$ に認められた.

表 3 に, 総合的重症度診断と客観的パラメーターと の関連を示す．男性において最大尿流率と残尿量は総 合的重症度と関連があったが，女性では関連は認めら れなかった. 24 時間尿量と夜間尿量では, 総合的重症 度とは関連が認められなかった，女性では昼間頻尿は 総合的重症度と関連があり, 男性では夜間頻尿は総合 的重症度と関連があった，尿失禁は，両性において重 症度の進行に伴い頻度が高くなった。すなわち, 軽症

表 2 総合的重症度と泌尿器科医の診断との関連

\begin{tabular}{|c|c|c|c|c|}
\hline 総合重症度 & 診断 & 男性 & 女性 & 計 \\
\hline 軽症 & 正常 & $14(48 \%)$ & $3(50 \%)$ & $17(49 \%)$ \\
\hline \multirow[t]{6}{*}{ (男：29,女：6) } & 過活動膀胱 & 0 & $2(33 \%)$ & $2(6 \%)$ \\
\hline & 前立腺肥大症 & $12(41 \%)$ & 0 & $12(34 \%)$ \\
\hline & 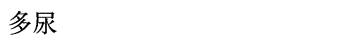 & $7(24 \%)$ & $1(17 \%)$ & $8(23 \%)$ \\
\hline & 夜間多尿 & $15(52 \%)$ & $4(67 \%)$ & $19(54 \%)$ \\
\hline & 低活動膀胱 & $2(6 \%)$ & 0 & $2(6 \%)$ \\
\hline & 神経症 & 0 & $1(17 \%)$ & $1(3 \%)$ \\
\hline 中等症 & 正常 & $3(6 \%)$ & $1(5 \%)$ & $4(6 \%)$ \\
\hline \multirow[t]{7}{*}{ (男 : 51, 女 : 21) } & 過活動膀胱 & $8(16 \%)$ & $11(52 \%)$ & $19(26 \%)$ \\
\hline & 前立腺肥大症 / 膀胱出口閉塞 & $36(71 \%)$ & $2(10 \%)$ & $38(53 \%)$ \\
\hline & 腹圧性尿失禁 & 0 & $2(10 \%)$ & $2(3 \%)$ \\
\hline & 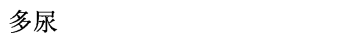 & $7(14 \%)$ & $5(24 \%)$ & $12(17 \%)$ \\
\hline & 夜間多尿 & $25(49 \%)$ & $13(62 \%)$ & $38(53 \%)$ \\
\hline & 低活動膀胱 & $10(20 \%)$ & $2(10 \%)$ & $12(17 \%)$ \\
\hline & 神経症 & $1(2 \%)$ & $3(14 \%)$ & $4(6 \%)$ \\
\hline 重症 & 正常 & 0 & 0 & 0 \\
\hline \multirow[t]{6}{*}{ (男：43,女：27) } & 過活動膀胱 & $24(56 \%)$ & $22(82 \%)$ & $46(66 \%)$ \\
\hline & 前立腺肥大症／膀胱出口閉塞 & $32(74 \%)$ & $1(4 \%)$ & $33(47 \%)$ \\
\hline & 腹圧性尿失禁 & $1(2 \%)$ & $6(22 \%)$ & $7(10 \%)$ \\
\hline & 多尿 & $4(9 \%)$ & $8(30 \%)$ & $12(17 \%)$ \\
\hline & 夜間多尿 & $23(53 \%)$ & $12(44 \%)$ & $35(50 \%)$ \\
\hline & 低活動膀胱 & $2(5 \%)$ & $5(19 \%)$ & $7(10 \%)$ \\
\hline
\end{tabular}


表 3 総合的重症度と客観的パラメーターとの関係

\begin{tabular}{|c|c|c|c|c|c|c|}
\hline & \multicolumn{6}{|c|}{ 平均 \pm 標準偏差 } \\
\hline & 総合的重症度 & 男性（123） & & & 女性（54） & \\
\hline \multirow[t]{3}{*}{ 最大尿流率（ml/s） } & 軽症 & $15.5 \pm 6.6$ & \multirow{3}{*}{$\begin{array}{l}0.01 * \\
<0.03 *\end{array}$} & $\neg$ & \multicolumn{2}{|l|}{$24.2 \pm 8.3$} \\
\hline & 中等症 & $12.2 \pm 4.9=$ & & \multirow[t]{2}{*}{$<0.0001^{*}$} & \multicolumn{2}{|l|}{$20.9 \pm 10.3$} \\
\hline & 重症 & $9.6 \pm 6.0$ & & & \multicolumn{2}{|l|}{$17.1 \pm 7.4$} \\
\hline \multirow[t]{3}{*}{ 残尿（ml） } & 軽症 & $11 \pm 11$ & \multirow{3}{*}{$\begin{array}{l}0.03 * \\
0.02 *\end{array}$} & \multirow{3}{*}{$<0.0001 *$} & \multicolumn{2}{|l|}{$16 \pm 19$} \\
\hline & 中等症 & $35 \pm 45$ & & & $26 \pm 38$ & \\
\hline & 重症 & $59 \pm 64$ & & & $17 \pm 19$ & \\
\hline \multirow[t]{3}{*}{24 時間尿量（ml） } & 軽症 & $1,873 \pm 668$ & & & $1,615 \pm 558$ & \\
\hline & 中等症 & $1,834 \pm 489$ & & & $1,910 \pm 892$ & \\
\hline & 重症 & $1,736 \pm 678$ & & & $1,845 \pm 584$ & \\
\hline \multirow[t]{3}{*}{ 昼間排尿回数 } & 軽症 & $9.6 \pm 10.9$ & & & $7.5 \pm 2.0$ & $\neg$ \\
\hline & 中等症 & $8.3 \pm 2.3$ & & & $9.4 \pm 3.2$ & 0.03* \\
\hline & 重症 & $9.3 \pm 2.9$ & & & $10.4 \pm 2.8$ & 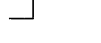 \\
\hline \multirow[t]{3}{*}{ 夜間尿量（ml） } & 軽症 & $636 \pm 266$ & & & $634 \pm 374$ & \\
\hline & 中等症 & $632 \pm 322$ & & & $682 \pm 337$ & \\
\hline & 重症 & $597 \pm 279$ & & & $571 \pm 276$ & \\
\hline \multirow[t]{3}{*}{ 夜間排尿回数 } & 軽症 & $1.4 \pm 0.9$ & & $\neg$ & $2.0 \pm 1.6$ & \\
\hline & 中等症 & $1.9 \pm 1.3$ & \multirow{2}{*}{$0.01^{*}$} & \multirow[t]{2}{*}{$<0.0005^{*}$} & $2.4 \pm 1.5$ & \\
\hline & 重症 & $2.6 \pm 1.7$ & & & $2.2 \pm 1.6$ & \\
\hline \multirow[t]{3}{*}{ ICIQ-SF 上の尿失禁 } & 軽症 & $0(0 \%)$ & & \multirow{3}{*}{$<0.0001 *$} & $0(0 \%)$ & \\
\hline & 中等症 & $3(6 \%)$ & & & $6(29 \%)$ & $<0.002^{*}$ \\
\hline & 重症 & $30(70 \%)$ & & & $22(82 \%)$ & \\
\hline
\end{tabular}

症例数 軽症: 男性 29 , 女性 6 , 中等症: 男性 51 , 女性 21 , 重症 : 男性 43, 女性 27

例は尿失禁例はなく，中等症例では男性で $3 / 51(6 \%)$, 女性で $6 / 21(29 \%)$, 重症例ではそれぞれ 30/43(70\%), 22/27（81\%）となっていた.

表 4 に, 総合的重症度診断と泌尿器科医が行った治 療との関係を示す。総合的重症度が軽症と判断された 35 例中 12 例 (34\%) はなにも治療を受けず, 8 例 (23\%) が水分制限の指導を受け，15例 (43\%) が薬物治療を 受けていた．中等症の 72 例中 8 例 (11\%) と重症の 70 例中 2 例 $(3 \%)$ のみが治療を受けなかった．治療とし ては, 薬物治療, 水分制限, 行動療法の順で頻度の高 い治療法となっていた.

\section{考察}

近年, 前立腺肥大症や尿失禁に対するいくつかの質 問票が作成されたが，排尿障害に対して男女共通に用 いることのできる質問票は未だ開発されていな い1718). I-PSS と QOL スコアは女性において妥当性の 検討は行われていないが, 女性においても臨床的に有 用であることがすでに示されている ${ }^{19)}$. 本研究では, 一般内科医が高齢男性・女性の蓄尿・尿排出障害の重 症度を正しく評価できるようにすることを目標とし て, I-PSS, QOL スコア, ICIQ-SF を使用して作成した
評価基準の有用性を調べることを目標とした ${ }^{20)}$ ．対象 となる高齢者は, 当然これらの質問票に回答すること のできる高齢者ということになる，以前，われわれは I-PSS，QOL スコア，残尿測定を用いた判定基準の有 用性を報告したが, 尿失禁を見逃す難点があったため, ICIQ-SF を追加した ${ }^{8)}$.

われわれは，内科医が排尿障害の診断を行う際に残 尿測定も重要であると考えた。この研究では，本間ら の推奨に従って残尿の重症度を $50 \mathrm{ml}, 100 \mathrm{ml}$ をカッ トオフとして採用した7). 米国泌尿器科学会の前立腺 肥大症診療ガイドライン (2003) では残尿に関するカッ トオフ值を設定する明確な根拠がないとされている.

しかし, Ouslanderは $100 \mathrm{ml}$ 以上の残尿は臨床的に問 題であろうと述べている ${ }^{13211}$. 本研究では，一定の評 価基準に基づいて内科医が治療することを前提として いる．高齢者では，過活動膀胱の存在とともに排尿筋 収縮力が低下している症例もかなり多い222. 過活動膀 胱に対する第一選択が抗コリン剂であることを考えれ ば，治療後の尿閉や残尿増大を防ぐためには $50 \mathrm{ml}$, $100 \mathrm{ml}$ はお扔むね納得のいくカットオフ值であろう. 当然, 治療後の超音波計測による残尿測定は必須であ 
表 4 総合的重症度と泌尿器科医の治療との関係

\begin{tabular}{|c|c|c|c|c|}
\hline \multirow{2}{*}{ 総合重症度 } & \multirow{2}{*}{ 治療 } & \multicolumn{3}{|c|}{ 治療を受けた患者数 } \\
\hline & & 男 & 女 & 計 \\
\hline 軽症 & なし & $12(41 \%)$ & 0 & $12(34 \%)$ \\
\hline \multirow[t]{3}{*}{ （男：29，女：6） } & 水分（カフェイン）撖取制限 & $6(21 \%)$ & $2(33 \%)$ & $8(23 \%)$ \\
\hline & 膀胱訓練／骨盤底筋訓練 & 0 & $1(17 \%)$ & $1(3 \%)$ \\
\hline & 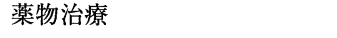 & $11(38 \%)$ & $4(67 \%)$ & $15(43 \%)$ \\
\hline 中等症 & なし & $5(10 \%)$ & $3(14 \%)$ & $8(11 \%)$ \\
\hline \multirow{4}{*}{ (男: 51 , 女: 21) } & 水分（カフェイン）摂取制限 & $14(28 \%)$ & $5(24 \%)$ & $19(26 \%)$ \\
\hline & 膀胱訓練／骨盤底筋訓練 & $1(2 \%)$ & $3(14 \%)$ & $4(6 \%)$ \\
\hline & 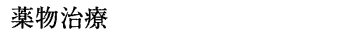 & $39(77 \%)$ & $14(67 \%)$ & $53(74 \%)$ \\
\hline & 手術 & $2(4 \%)$ & 0 & $2(3 \%)$ \\
\hline 重症 & 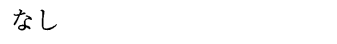 & $1(2 \%)$ & $1(4 \%)$ & $2(3 \%)$ \\
\hline \multirow[t]{4}{*}{ （男：43，女：27） } & 水分（カフェイン）摂取制限 & $9(21 \%)$ & $6(22 \%)$ & $15(21 \%)$ \\
\hline & 膀胱訓練／骨盤底筋訓練 & $3(7 \%)$ & $6(22 \%)$ & $9(13 \%)$ \\
\hline & 薬物治療 & $40(93 \%)$ & $23(85 \%)$ & $63(90 \%)$ \\
\hline & 手術 & $6(14 \%)$ & 0 & $6(9 \%)$ \\
\hline
\end{tabular}

\section{ると考えられる.}

第一に，一般内科医の評価基準を用いた重症度と泌 尿器科医の診断とを比較検討した. この研究では, 男 女とも正常の排尿を最大尿流率 $15 \mathrm{ml} / \mathrm{sec}$ 以上かつ残 尿 $50 \mathrm{ml}$ 未満で尿意切迫感や尿失禁を有しないことと した．女性の最大排尿率 $15 \mathrm{ml} / \mathrm{sec}$ は基準として低す ぎる感もあるが, 高齢者を主な対象者としている点を 考慮すれば妥当でないとは必ずしも言い切れないと思 われる. Chassegne らは, 女性の膀胱出口閉塞の指標 として最大尿流率 $15 \mathrm{ml} / \mathrm{sec}$ をカットオフ值として提 唱している ${ }^{23)}$.

男性, 女性とも「正常の排尿」と判断された症例は, 重症と判定された 70 例では 1 例もなく, 中等症の 72 例ではわずか 4 例だけであった．軽症の 35 例では 17 例 $(49 \%)$ が正常の排尿と診断されたが，男性の 12 例 (41\%) が前立腺肥大症と，女性の 2 例 $(33 \%)$ が 過活動膀胱と診断された．軽症例の約半数が何らかの 疾患ありとされた理由としては, 本研究に参加した 6 名の泌尿器科医の診断法に差があったこと, 程度の差 こそあれ困ることがあって泌尿器科を訪れた患者を対 象としていることなどがあげられる.

排尿障害に関する一般内科医向きの重症度評価基準 が適当か否か検討するために, 泌尿器科医が行う診療 でその基準を当てはめた際の有効性を調查したのが本 研究である. 今後, 一般内科医がこの基準を用いて診 療を行い，有用性を検討する必要があろう．その際に は, 軽症例で正常と判断される症例はもっと多くなる
と推定される.

本研究では多尿は軽症例でも $23 \%$ の症例に認めら れ, 多尿も夜間多尿も重症度に関わらず一定の頻度で 認められた. 本邦においては, 血液の粘稠度を下げ脳 梗塞や心筋梗塞を防ぐために, 多くの高齢者が多量の 水や掞茶などを摂取するよう勧められている。 むやみ な水分摂取を避けるために，一般内科医の診療にも排 尿記録を取り入れるよう勧めたい，それにより昼間・ 夜間の尿量がわかり，水分摂取を増やした方がよいの か, あるいは制限した方がよいのか, きめの細かい生 活指導が可能となると考えられる ${ }^{24)}$.

両性とも, 尿失禁の頻度は総合的重症度が上がるに 従い高くなった. 男性では最大尿流率の低下, 残尿量 の増加, 夜間頻尿が重症度と関連があり, 女性では昼 間頻尿が重症度と関連があった，高齢男性では前立腺 肥大症と過活動膀胱が, 女性では過活動膀胱が大きな 問題であると考えられた。

次いで, 重症度と泌尿器科医による治療との関連を 検討した． 総合重症度が重症であった 70 例のうち, 2 例は治療を受けていなかった. 1例は巨大な前立腺肥 大症を有していたにもかかわらず治療を希望せず，他 の 1 例は他疾患の悪化のため評価後に受診できなかっ たためである.中等症と判定された 72 例中 8 例が治療 を受けなかった. これらの症例のうち, 2 例が正常の排 尿と診断されていた. 他の 6 例は低活動膀胱 2 例, 腹 圧性尿失禁と過活動膀胱, 多尿, 神経症の各 1 例であっ た.これらのことから, 今回用いた基準により総合的 
に中等症，重症と診断された症例のほとんどが治療が 必要な症例であると考えられた。

軽症と判断された 35 症例のうちの 12 例（34\%）に 対して泌尿器科医は何も治療しなかったが，8例 （23\%）に水分制限を行い 15 例（43\%）に薬物療法を 行った．薬物療法を行った女性 4 例（プロピベリン 2 例，オキシブチニン 1 例，フラボキセート 1 例）の MFR はいずれも $15 \mathrm{ml} / \mathrm{s}$ 以上で残尿 $50 \mathrm{ml}$ 未満, 主な 投薬理由は昼間頻尿 2 例, 薬剂希望 (神経症) 1 例, 尿 意切迫感 1 例であった．男性 11 例（夕ムスロシン 9 例，ウラピジル 2 例)のうち 3 例は MFR $15 \mathrm{ml} / \mathrm{s}$ 以上, 8 例は $5 \sim 15 \mathrm{ml} / \mathrm{s}$ で全例残尿 $50 \mathrm{ml}$ 未満であり, 投薬理 由は尿勢低下 7 例，夜間頻尿 2 例，昼間頻尿 1 例，前 立腺腫大 1 例であった．医学的な問題は全く認められ なかった，症状がひどくなく，困っていないと答えた 軽症例であれば，投薬しなかったとしても非難される ことはないと考えられる。 また, 軽症例でも $20 \%$ 程度 は排尿日誌をもとに水分制限が必要な症例があること がわかった.

結論として, ICIQ-SF を加味した I-PSS と QOL スコ ア，残尿測定からなる高齢者排尿障害の基準は，一般 内科医の診療に有用であろうと考えられた，総合的重 症度が中等症あるいは重症と判定された症例に対して は治療を行うのが適当であろう。一般内科医が行う診 療において，今後，この判定基準の有用性を評価する ことが必要であると考えられた。

本研究は, 平成 15 年度厚生労働省長寿共同研究費 (15-1) と平成 16 年度厚生労働科学研究費補助金長寿科学総合研 究事業（H16-長寿-008）の助成を受けて行われた.

\section{文献}

1) Okamura $K$, Usami $T$, Nagahama $K$, Maruyama $S$, Mizuta E: "Quality of life" assessment of urination in elderly Japanese men and women with some medical problems using International Prostate Symptom Score and King's Health Questionnaire. Eur Urol, 41, 411-419, 2002.

2) Araki I, Zakoji H, Komuro M, Furuya Y, Fukasawa $\mathrm{M}$, Takihana $\mathrm{Y}$, Takeda $\mathrm{M}$ : Lower urinary tract symptoms in men and women without underlying disease causing micturition disorder : a cross-sectional study assessing the natural history of bladder function. J Urol, 170, 1901-1904, 2003.

3) Terai $A$, Matsui $Y$, Ichioka $K$, Ohara $H$, Terada $N$, Yoshimura $\mathrm{K}$ : Comparative analysis of lower urinary tract symptoms and bother in both sexes. Urology, 63, 487-491, 2004.
4) Abrams P, Cardozo L, Fall M, Griffiths D, Rosier P, Ulmsten U, Van Kerrebroeck P, Victor A, Wein A : Standardization sub-committee of the International continence society. The standardization of terminology of lower urinary tract function : report from the standardization subcommittee of the International Continence Society. Neurourol Urodyn, 21, 167-178, 2002.

5) Garnett $S$, Abrams $P$ : The natural history of the overactive bladder and detrusor overactivity. A review of the evidence regarding the long-term outcome of the overactive bladder. J Urol, 169 , 843-848, 2003.

6) Okamura K, Usami T, Nagahama K, Maruyama $S$, Mizuta $\mathrm{E}$ : The relationships among filling, voiding subscores from International Prostate Symptom Score and quality of life in Japanese elderly men and women. Eur Urol, 42, 498-505, 2002.

7) Homma $Y$, Kawabe $K$, Tsukamoto $T$, Yamaguchi O, Okada K, Aso Y, Watanabe H, Okajima E, Kumazawa J, Yamaguchi T, Ohashi Y : Estimate criteria for diagnosis and severity in benign prostatic hyperplasia. Int J Urol, 3, 261—266, 1996.

8）岡村菊夫, 長浜克志, 宇佐美隆利, 長田浩彦, 安部 崇重, 勝野 暁, 川野圭三, 佐藤滋則, 原田雅樹 : 高齢者排尿障害の初期評価法一患者・介護者・看 護師, 一般内科医, 泌尿器科医レベルの評価法の比 較一. 日老医誌, 40 (4), 360-367, 2003.

9）本間之夫, 柿崎秀宏, 後藤百万, 武井実根雄, 山西 友典, 林 邦彦: 排尿に関する疫学的研究. 日本排 尿機能学会誌, 14, 266一277, 2003.

10) Milsom I, Abrams P, Cardozo L, Roberts RG, Thuroff J, Wein AJ : How widespread are the symptoms of an overactive bladder and how are they managed? A population-based prevalence study. BJU Int, 87, 760-767, 2001.

11) Stewart WF, Van Rooyen JB, Cundiff GW, Abrams P, Herzog AR, Corey R, Hunt TL, Wein $\mathrm{AJ}$ : Prevalence and burden of overactive bladder in the United States. World J Urol, 20, 327-336, 2003.

12) Andersson $\mathrm{KE}:$ Storage and voiding symptoms : pathophysiologic aspects. Urology, 62, 3-10, 2003.

13) Ouslander JG : Management of overactive bladder. N Engl J Med, 350, 786-799, 2004.

14) Athanasopoulos A, Gyftopoulos K, Giannitsas K, Fisfis J, Perimenis P, Barbalias G: Combination treatment with an a-blocker plus an anticholinergic for bladder outlet obstruction : a prospective, randomized, controlled study. J Urol, 169, 22532256, 2003. 
15) Serels $S$, Stein $M$ : Prospective study comparing hyoscyamine, doxazosin, and combination therapy for the treatment of urgency and frequency in women. Neurourol Urodyn, 17, 31-36, 1998.

16) Swanson JG, Skelly J, Hutchison B, Kaczorowski $\mathrm{J}$ : Urinary Incontinence in Canada. National survey of family physicians' knowledge, attitudes, and practices. Can Fam Physician, 48, 86-92, 2002.

17) Barry MJ, Fowler FJ, O'leary MP, Bruskewitz RC, Hotgrewe HL, Mebust WK, Cockett ATK and the measurement committee of the American Urological Association: The American Urological Association symptom index for benign prostatic hyperplasia. J Urol, 148, 1549-1557, 1992.

18）後藤百万, Donovan J, Corcos J. Badia X, Kelleher CJ, Naughton M, Shaw C, Avery K, 本間之夫 : 尿 失禁の症状・QOL 質問票 : スコア化 ICIQ-SF (International Consultation on Incontinence-Questionnaire: Short Form). 日本神経因性膀胱学会誌, 12, 227-231, 2001.

19) Chancellor MB, Rivas DA : American urological association symptom index for women with voiding symptoms : Lack of index specificity for be- nign prostate hyperplasia. J Urol, 150, 1706—1709, 1993.

20）岡村菊夫; 野尻佳克, 大島伸一：一般内科医のため の高齢者排尿障害診療マニュアル．http://www/ ncgg.go.jp, 2005.

21) AUA practice guidelines committee. AUA guideline on management of benign prostatic hyperplasia (2003). Chapter 1 : Diagnosis and treatment recommendations. J Urol, 170, 530-547, 2003.

22) Resnick NM, Yalla SV : Detrusor hyperactivity with impaired contractile function. An unrecognized but common cause of incontinence in elderly patients. JAMA, 257, 3076-3081, 1987.

23) Chassagne S, Bernier PA, Haab F, Roehrborn CG, Reisch JS, Zimmern PE : Proposed cutoff values to define bladder outlet obstruction in women. Urology, 51, 408-411, 1998.

24）岡村菊夫，塈見幸彦，遠藤英俊，德田治彦，志賀 幸夫, 三浦久幸, 野尻佳克：「水分を多く摂取する ことで, 脳梗塞や心筋梗塞を予防できるか?」シス テマティックレビュー。 日老医誌, 42, 557-563, 2005.

（2005 年 5 月 30 日受付， 8 月 17 日受理） 